\title{
Quando e por que é bom ler poesia
}

\author{
Maria Theresa Abelha Alves *
}

O novo livro da renomada medievalista Ângela Vaz Leão, Cantigas de Afonso X a Santa Maria (antologia, tradução e comentários) é uma feliz resposta à pergunta com que intitulo esta resenha. Ler poesia é bom quando se é conduzido pelo saber e pela sensibilidade, qualidades que sobejam na Autora, Ângela Vaz Leão, e que o leitor de seu livro constata, quer pela inteligente seleção de quarenta e dois poemas paradigmáticos da variedade de temas abordados pelo "Rei Sábio", quer pela belíssima tradução que ela faz para o português contemporâneo do original galego-português. Para selecionar com critério e, principalmente, bem traduzir, mantendo-se ritmo e rima do original, façanha nesta obra conseguida com esmero, é necessária a fineza interpretativa que decorre de conhecimento e de muita sensibilidade. É o grande conhecimento que conduz o Estudo Introdutório em que a especialista, fornecendo dados biográficos do Rei Afonso X, dados sobre as características dos quatro manuscritos que chegaram até nós e explicações acerca de elementos das Cantigas, expõe seus critérios de abordagem textual dos "milagres" e das "loas" da obra do trovador da Virgem, obra que a ilustre mestra leu como deve ser lida: com saber e sabor. É a superlativa sensibilidade que alicerça os comentários e paráfrases, adjuntos aos poemas selecionados, de modo a encaminhar o leitor na mentalidade da época e na visão de mundo e nos valores do Rei em cuja corte as Cantigas de Santa Maria se produziram ou se recolheram. Guiados assim por Ângela Vaz Leão, seus leitores também descobrem o saber da poesia, no duplo sentido que este verbo tem em português: conhecimento e gosto.

Centro Universitário Jorge Amado - UNIJORGE. 
O cancioneiro sacro de Afonso X apresenta dois Prólogos, em forma de poemas: o A e o B, que também são os primeiros a figurarem na presente edição. O Prólogo A tece o elogio do soberano, segundo os protocolos que ilustram o perfil do herói, na sociedade medieval, nomeadamente na Península Ibérica motivada pelo projeto da Reconquista. O retrato do Rei que aí se pinta condiz com o paradigma de "heróis e soberanos", tal como foi exposto por Ernst Curtius, a partir dos valores básicos de santidade, sabedoria, nobreza, utilidade e agrado a que corresponderiam cinco personalidades: o santo, o gênio, o herói, o dirigente, o artista. O Prólogo A apresenta um protocolo de verossimilhança: a voz da cantiga pertence a alguém que teria achado o cancioneiro e que passa então a enumerar as conquistas e as virtudes régias. O soberano é pintado com a espada e a fé com que ele dilatou seus domínios e com a pena com que se mostrou poeta de Santa Maria. A abrangência dos territórios conquistados condiz com a ascensão da figura régia. Ilustra-se assim que, em D. Afonso X, o heroísmo, a capacidade guerreira, a fé, a sapiência e a arte se mesclam, na convergência feliz de ethos e crença que evidencia o binômio valor-sabedoria que configura o herói medieval. As virtudes do rei expressas no Prólogo A fazem-no também exemplo daquilo a que Jacques Le Goff considerou o novo ideal majestático que se formulava na Baixa Idade Média: o do rei erudito que usa a língua vulgar, e não o latim, na difusão de sua cultura.

Já o Prólogo B, em primeira pessoa, alude ao que é necessário para bem trovar. É uma "arte poética" que considera ser indispensável ao trovador ter entendimento, bom assunto e arte. $\mathrm{O}$ eu lírico, que se confunde com o autor das Cantigas (ou suposto autor), modestamente se apresenta desprovido de arte, mas empenhado em louvar a Virgem e difundir seus milagres, assunto bom já à partida. Se a arte lhe falta, ele possui o bom assunto ou razão e conta com a ajuda de Deus e da própria Maria a quem devota grande amor. Assim, ele, que já fora previamente qualificado pelo Prológo A, mais ainda se qualifica perante seus ouvintes ou leitores, e, ao mesmo tempo, qualifica a obra que lhes dá ao deleite: obra cujo tema é entre todos o melhor e executada com a mais sublime das parcerias.

A excelência da obra que tem Maria como assunto e Ela e Deus como ajudantes mais tarde, na Cantiga 209, que tem o próprio rei D. Afonso X como beneficiário de um milagre de cura, haveria de se confirmar, porque o prodígio se dá depois que o rei põe sobre seu corpo doente o livro das Cantigas de Santa Maria, adquirindo o mesmo o estatuto de objeto lustral, sagrado, tal como uma relíquia salvadora. 
Como ocorre na poesia profana da época, o eu lírico do Prólogo B rende um preito ao objeto de amor com seu canto, fazendo dele uma prova de fidelidade amorosa que merece o "gualardon", a recompensa almejada, "com'ela dá aos que ama". Propondo deixar de cantar a outras mulheres e endereçando seu trovar apenas a Maria, o trovador transmuta a vassalagem amorosa do trovadorismo em enlevo místico, evidenciando que são muito imprecisas as fronteiras entre as duas eróticas na poesia medieval, a do corpo e a da alma, posto que temas profanos foram transferidos para a poesia religiosa e temas místicos para a profana. Se uma das funções para-textuais do prólogo é apresentar o conteúdo do livro e encaminhar o leitor na travessia da leitura, o Prólogo B cumpre muito bem tal função: propaga o assunto do cancioneiro e sugere que à Virgem o devoto rende um preito de amor, uma vassalagem amorosa. Se uma tópica recorrente nos poemas amorosos de todos os tempos consiste na confissão do amador de que é incapaz de fazer justiça às qualidades da amada, ou porque lhe faltam as devidas palavras ou porque lhe falta tempo de vida, a mesma tópica se verifica na Cantiga 110, porém como sentimento místico, porque como se repete no refrão: "Tant'é Santa Maria de ben mui comprida, que para a loar tempo nos fal e vida".

$\mathrm{O}$ culto mariano influenciou o culto à mulher $\mathrm{e}$, de igual modo, o amor à mulher contaminou o culto mariano tornando tênues os limites entre ambos, talvez porque no pensamento escolástico toda beleza e excelência eram, nos seres humanos, manifestações do divino, de modo que uma bela mulher, capaz de despertar a irresistível paixão cortês, era também comprovação terrena da suprema maravilha da mãe de Deus, senhora a quem todo o amor maior era devido. Assim, em algumas das demais Cantigas de Santa Maria, metáforas com que se designou a mulher nos cantares profanos de erótica corporal para ratificar a beleza feminina são retomadas pelo cancioneiro sacro do Rei fiel, como símbolos da Virgem.

O trovador Guillaume de Lorris, no Romance da rosa, obra profana, descreve as peripécias de um homem da corte para conquistar sua amada, representada por uma rosa, esta que é metáfora vegetal da mulher. É também com a imagem da flor que se tece o elogio a Maria, na Cantiga 10, mediante o aproveitamento do chamado "superlativo bíblico": Maria é, para o sujeito poético, "Rosa das rosas e Flor das flores", superior a todas as demais rosasmulheres em beldade, parecer, alegria e prazer. Com semelhante superlativo, o eu-lírico intensifica o que propusera no Prólogo B: trocar o preito amorosopoético endereçado a outras damas pelo preito àquela que as supera. A 
dualidade sacro-profana se confirma na última estrofe do poema que poderia, com toda pertinência, ser estrofe de uma "cantiga de amor". O primeiro verso desta última estrofe também aparece em poemas lírico-amorosos do período, com pequenas variações. Bernal de Bonaval, por exemplo, apresenta como primeiro verso (ou "palavra" para ser fiel à nomenclatura medieval) de uma de suas "cantigas de amor" o seguinte: "A dona que eu am'e tenho por Senhor". Outras cantigas celebram os incomparáveis atributos da Virgem por meio de outras metáforas que a tradição trovadoresca atribuiu à mulher, tais como “estrela" e "ave", mas como "ave", Maria se opõe a "Eva".

Maria é rosa, estrela e ave de superior beleza, maior luz e inigualável pureza por suas virtudes canônicas, Ela que é "a sen par luz e verdadeira": filha e mãe de Deus, advogada dos homens, intermediária da misericórdia divina. Tais virtudes se confirmam pelos "milagres" em que Ela figura como intercessora em curas prodigiosas das maleitas físicas (tais como o fogo selvagem e a lepra), em ressurreições miraculosas, como se expressa na Cantiga 118. Tais virtudes são as que fazem o poder mariano suplantar todo o diabólico mal, como as Cantigas 41 e 90 confirmam. Os cantares sacros da coletânea de Afonso X advogam a oração como culto de amor à Maria, culto a que Ela, agradecida, confere valor lustral e salvador. Pelas preces que lhe são dedicadas, Maria salva o corpo e alma dos seus devotos, perdoa-lhes o pecado e pode até devolvê-los à vida, como se expõe na Cantiga 111, onde Ela ressuscita, depois de três dias de morto, um clérigo que se afogara.

O Rei cujo empenho devocional de amor é enaltecer as qualidades ímpares da Virgem encontra seu "duplo" na figura do jogral distinguido com um milagre mariano. Não são apenas as cantigas de "loor" que retomam um protocolo da cantiga profana: a devoção do trovador a seu objeto de amor, preito de fidelidade marcado pela repetição, os milagres também o reproduzem. A Cantiga 8, por exemplo, narra o "milagre" com que a Virgem premiou um devoto jogral que lhe tributava vassalagem. A devoção desse jogral é similar a que o Rei advogara para si, no Prólogo B: trovar à Maria é tributo de amor. Sintomático a esse respeito é o fato de se nomear como "lais" o cantar desse jogral, pois o "lais" é um dos tipos de cantares provençais de amor. Sintomático a esse respeito é ainda o "galardão" a que o jogral almeja com seu canto: uma candeia acesa para iluminar uma ceia. Candeia é símbolo ao mesmo tempo da graça santificante, pelo caráter purificador do fogo, mas é também símbolo erótico. A ceia que seria iluminada com o prêmio dado por Maria é elemento igualmente polarizado: ágape que enseja a comunhão mística e filia que se 
manifesta como profana comida. A mesma tópica do cantar como preito se verifica em muitas outras cantigas. O canto, transformado na mais piedosa e eficaz oração, seria um estágio da vassalagem amorosa, já agora prestada e devida à mulher soberana entre as demais.

Embora haja interferência de duas experiências amorosas, a celeste e a mundana, o eu lírico não deixa de expor as características de uma e outra, segundo a oposição que a Igreja fazia entre ambas. Um milagre se encarrega disso, é o relatado na Cantiga 312, em que um pio Cavaleiro, devoto da Virgem a quem tributava amor, trocou este vero amor, marcado pela casta fidelidade à Maria, pelo amor à Dama de bom parecer, a quem passa a servir, almejando o prazer carnal. Este amador inverteu o que fora proposto no Prólogo B. Segundo o código do amor cortês, passa então por todos os estágios da coita amorosa: perde a fome, o sono e o senso, na ânsia do encontro que, entretanto, jamais se realiza, pois ele fizera uma indevida e má troca, trocara o verdadeiro pelo falso amor.

Mas por que é bom ler poesia? A resposta também se encontra neste livro, porque a bem cuidada seleção das Cantigas que se apresenta é um convite ao diálogo que permite ao leitor trabalhar com inúmeras hipóteses de leitura, experimentando travessias intratextuais ou estabelecendo pontes intertextuais. Não é possível deixar de aceitar tão aliciante e sedutor convite. Este novo livro de Ângela Vaz Leão desperta no leitor o prazer de ler, aquele prazer barthesiano de ler levantando a cabeça. Se a literatura comporta todos os demais saberes, o cancioneiro sacro de Afonso X é a confirmação disso, ofertando ao leitor vários caminhos em que geografia e história, sociologia e antropologia, filosofia e psicologia, a cultura oficial e a marginal se encontram e se conformam.

Se o leitor quiser percorrer este rico manancial de conhecimentos mediante uma via histórica, poderá surpreender a evolução e a extensão do culto mariano mediante as inúmeras igrejas referidas nas Cantigas, não só de várias regiões da Espanha como de muitos outros países, pois que era o "tempo das catedrais", como Georges Duby tão bem soube nomear a época. Poderá acompanhar o progresso da Reconquista e do poderio régio. Poderá ainda surpreender a mentalidade da época e o modo de interação dos diferentes estamentos.

Se ele se aventurar por uma via sociológica poderá acompanhar os diferentes agentes sociais que configuram o quadro antropológico da sociedade medieval e a que as cantigas se referem. A de número 8 apresenta as figuras do monge tesoureiro, que reaparece na Cantiga 11, e do jogral. O jogral importava à época 
como verdadeiro agente de opinião, indo e vindo de um lugar para o outro com seus cantares e novidades. Na Cantiga 8, o par monge tesoureiro e jogral encena a tópica medieval do "mundo às avessas". O monge tesoureiro, que deveria ser figura exemplar de crença é, no entanto, o incrédulo, o que duvida do milagre, ao passo que o jogral, mundano por sua própria natureza andarilha, é o fiel. Já na Cantiga 11, o monge tesoureiro é amasiado e esquecia de seus afazeres. A insistência em conferir atributos negativos aos monges tesoureiros é índice de um dado econômico do século XIII, quando os monarcas começaram a se sentir ameaçados pelo patrimônio da Igreja e adotaram uma política de concentração do capital nos cofres régios, condenando outra qualquer prática de entesourar haveres, inclusive a religiosa. Outros representantes da tipologia social da Idade Média se ilustram, a Cantiga 242, por exemplo, apresenta como beneficiário do milagre da Virgem um pedreiro de Burgos. O pedreiro foi figura de grande importância no tempo em que as catedrais, como a de Burgos, se ergueram. A Cantiga 312 focaliza o cavaleiro, a dama e a alcoviteira. O cavaleiro era figura considerável na região pelo projeto da Reconquista, a alcoviteira, de cujos serviços a sociedade de então usufruía e a quem simultaneamente execrava, era o importante canal intermediador do comércio dos afetos e dos pecados e que séculos depois iria reaparecer em La Celestina, de Fernando de Rojas e no teatro de Gil Vicente como tipo social ibérico. Muitas das cantigas fazem alusão aos clérigos, nomeadamente os monges, cujo perfil de agentes da fé surge alterado, pois que, na maioria das vezes, são eles os incrédulos, os prevaricadores, os que duvidam dos planos de Deus ou os que agem em desconformidade com o que pregam. Tais atributos negativos, entre outros, seriam os que geraram descontentamentos que levariam às várias questões religiosas (ou heresias) do tempo.

Além de tais tipos sociais, as cantigas aludem também aos judeus, que configuravam uma parcela considerável da sociedade, ou lhes concedendo o atributo da sovinice, ou acreditando serem eles sujeitos de ações sacrílegas, ou relatando conversões, o que tanto evidencia o desprezo que lhes devotavam as gentes como o projeto de uma hegemonia de culto, camuflados um e outro, posto que à Coroa interessavam os pensamentos e os cabedais judeus. Sobre a maneira velada com que se insuflava um sentimento antissemítico é paradigmática a Cantiga 12 que reproduz uma estratégia de convencimento do povo, no sentido de aniquilar as diferenças, mediante o procedimento analógico medieval: na hora da imolação do Cordeiro na missa, cena igual se processava na judiaria. Para evitar que outra vez o Cristo fosse imolado, ainda 
que em "omagen de cera", a própria Virgem, a quem o "que mais despraz, é de que ao seu Filho pesar faz", impõe um outro holocausto, o dos judeus, que "por est' ouveron todos de morrer". Entre os "milagres" apresentados, alguns se inserem na conjuntura de conversão dos infiéis, pois a diversidade religiosa da Península Ibérica convivia com um projeto de padronização de culto que corria em paralelo com o da Reconquista.

Se o leitor quiser enveredar por uma via psicológica, encontrará os anseios e os terrores, os sonhos e os pesadelos, os amores e os ódios que estruturam a psique medieval. O leitor encontrará ainda subsídios para o estudo das crendices da Baixa Idade Média, tais como o valor atribuído às relíquias, ao poder curativo do leite, à convivência e ingerência do maravilhoso no cotidiano.

Se quiser percorrer as cantigas por uma via antropológica encontrará lendas populares da época, como a exposta pela Cantiga 103, que ilumina as diferenças entre o tempo limitado dos homens e o tempo ilimitado de Deus, lenda esta que haveria de reaparecer no Barroco, reaproveitada por Padre Manuel Bernardes, ou a exposta pela Cantiga 13, que teve na época uma versão em prosa e, no século XX, serviu de hipotexto para uma novela de Jorge de Sena. Ou ainda a exposta na Cantiga 52, em que Maria, através das cabras que se enfileiravam para a ordenha, alimentou todo um mosteiro até que um "crerizon sandeu" comeu um cabritinho e a ordenha milagrosa não mais se deu, lenda esta que referenda uma das infrações daquele tempo expostas nos livros de caça: o abate de filhotes.

O livro ainda brinda seus leitores com a reprodução a cores de algumas das iluminuras que enriqueciam o cancioneiro, com a partitura musical de algumas das cantigas e com um $\mathrm{CD}$ em que seis delas são musicalmente interpretadas pelo conjunto de música antiga Chorus Rosa Rosarum, sob a direção de Sérgio Antônio Canedo. Pelas iluminuras os leitores de hoje podem se dar conta dos instrumentos com que eram executadas as cantigas: fídulas, rabecas, alaúdes, cítaras, harpas, flautas, cornamusas, pratos, castanholas, sinos, organistrum, e podem também verificar a coreografia que acompanhava o canto a uma ou mais vozes, demonstrando assim o caráter performático da poesia medieval que não pode ser olvidado, conforme ensina o estudioso Paul Zumthor, em A letra e a voz. As iluminuras funcionam como as bandas desenhadas de hoje e encerram uma narrativa mediante a imagem. Tal é, por exemplo, o caso da ilustração da Cantiga 8, que focaliza o milagre concedido ao jogral que homenageava a Virgem com sua música e foi por Ela premiado com uma candeia, conseguindo com isso abrandar o coração incrédulo de um 
monge e fazer acorrer à igreja grande quantidade de romeiros. Os seis quadros que compõem a página iluminada figuram as sequências narrativas do milagre, reduplicando pela imagem o conteúdo semântico da Cantiga. O mesmo se dá com as iluminuras que reproduzem a lenda da ordenha milagrosa.

As Cantigas de Santa Maria são uma manifestação poética da arte gótica. Tais como as catedrais construídas na mesma época, o cancioneiro sacro de Afonso $\mathrm{X}$ funcionava, e funciona ainda, como um irrecusável convite à fruição através do gozo estético provocado pela excitação dos sentidos. No tempo das catedrais, o que tornava prazerosa a relação humano e divino era o apelo sensório. Este livro reproduz este apelo e se faz fonte de conhecimento e gozo não só pela letra original e pela tradução das cantigas mas também pelo recurso audiovisual, numa festa de som e letra, cores e sentidos. As melodias das Cantigas possibilitam resgatar o leque de suas influências: há melodias que parecem reproduzir o canto litúrgico clássico, outras que se apoiam numa vertente arábico-andaluza, outras que exploram as melodias occitânicas.

Visitar a Idade Média e seus enredos místicos guiados pela sabedoria de Ângela Vaz Leão é o convite que este belo livro nos faz, dando-nos a certeza de que é bom, muito bom, ler poesia. 